\title{
Influence of marital communication on family stability of married teachers in Nsukka education zone
}

\author{
Joachim Chinweike Omeje, Benedeth Lebechi Ugwu* and Chinenye Ifeoma Ogidi \\ Department of Educational Foundations, University of Nigeria, Nsukka, Nigeria.
}

Received 12 November, 2020, Accepted 11 March 2021

\begin{abstract}
This study examined the influence of marital communication on the family stability of married teachers in the Nsukka Education Zone of Enugu State. It was guided by two research questions and two hypotheses. The population comprised 1688 married teachers in Nsukka Education Zone secondary schools. A correlation design was adopted for the study. The sample was 455 respondents. Proportionate stratified sampling techniques were used to select the sample from the parent population. The instrument for data collection was a questionnaire. The instrument has been validated by two experts from the Educational Foundations and one from the Faculty of Education, University of Nigeria Nsukka, Measurement and Evaluation. The reliability of the instrument's internal consistency was developed using Cronbach Alpha statistics. Mean and Standard Deviation were used to answer research questions one while the Pearson product-moment correlation coefficient was used to answer research question two. T-test statistics was used to test the two null hypotheses. There is a significant positive relationship $(p<0.05)$ between marital communication and family stability of married teachers. Recommendations and implication were made based on the study results. Married teachers should not align family issue to types of communication in the prevailing situation amongst others.
\end{abstract}

Key words: Marriage, communication, marital communication, family stability, married teacher.

\section{INTRODUCTION}

Marriage is a very important event in the life of any individual. Marriage is strongly supported in Nigerian and African culture because people believe that it is an institution ordained by God as well as our various cultures. Marriage is a sacred union between a man and a woman, and it is a lifelong relationship between married couples since marriage is better or worse right from the beginning (Onovo, 2016). Marriage is recognized by our society as a transaction or contract between a woman and a man which gives them a continuing claim to the right of sexual access to one another, eligibility to bear legitimate children. Salami (2007) views marriage as the final stage of love between the opposite sex, devoid of disunity; and makes them take full responsibilities for themselves and the environment for better or worse till death take them apart.

Marriage is a sacred condition that is meant to be a special life partnership and to merge the husband and wife harmoniously into being one person. Both parties are expected to be helpful to each other so that good understanding should exist between them to promote Mutual trust (Nnadozie, 2014). Marriage requires both

${ }^{*}$ Corresponding author. E-mail: lebechibenedeth@gmail.com. Tel: +2347036312579. 
husband and wife to communicate ideas, perceptions and views to grow the family. Uwakwe (2008) stated that communication is the bedrock of all interpersonal relationships and involves a meeting between individuals who are constantly conscious of each other for an intentional sharing of emotions, ideas, values, feeling and general experience.

Marital communication refers to the verbal and nonverbal exchange of information between spouses. It is the process of sending and receiving messages between husband and wife as they interact in the marriage relationship (Nnadozie, 2014). It helps the partners to know, share and understand a lot of things in common which includes: their thoughts, emotions, past experiences and weaknesses within and outside the relationship. Nnadozie (2014) believes that effective marital communication is the live-wire that links husband and wife together, strengthens the bond of relationship and so propels all activities in the family. Marital communication has been studied most widely in the context of heterosexual relationships. Most frequently with comparisons being made in communication behaviors associated with relationship satisfaction between the communications behaviors of satisfied and dissatisfied couples.

Marital communication helps to build up courage which is one of the character traits in any successful marriage. Couples can hold on to the viewpoint of the other in marital affairs despite influence from the significant outsiders. It takes effective communication to make different individuals (husband and wife) with different ideologies to live together. When they come together they know each other very well through various ways of communication. However, communication enhances the understanding, clears up those doubts that have already occurred, promotes the decision-making process in the home and as well offers mental and creative expressions by the couples over the performance of their domestic responsibilities and duties (Okorodudu, 2010). The researcher views marital communication based on character traits (such as trust, love, oneness of mind, and honesty in marital relationship and courage in the lives of family members) as well as style of communication (The use of more expressive, tentative and polite language by women than men, especially in the situation of conflict) can lead to family stability.

Family stability is referred to as a family that has a good marriage relationship where the married couples love one another, think alike, share common goals, interest, joy and work out problems together (Eze, 2012). The married couples are really good friends, able to talk to one another. When a family is coping with issues related to in-laws, family finance, providing family needs, doing their domestic chores, interpersonal communication, sexual relationship, emotional adjustment, health problems among others, there will be family stability. The stability of the family is believed to occur in families whose parents are stable and receive money. Though, many issues may arise leading to a disagreement between family members occasionally and then resolve it peacefully without experiencing housing changes. Family unity members live together for immigration and job-seeking purposes, with no unusual divorce and remarriage or few separations (Patterson and Yoevger, 2002). There are several effects of family stability on children; family stability leads to more successful child care and parental control, less family conflict, and more family unity.

Family stability is defined as the level of day to day family events as the predictability and consistency of family activities and routines measured with the stability of activities in the family environment (Okonkwo, 2006). The family is the basis of societal sustainability. The stability of the family is relatively proportional to the stability, peace and orderliness of the society. Tambuwal (2007) defined family stability as consistency in activities or events expected in the family setting by all the members of the family. This comes to be as a result of concerted effort and concentrated desire of the couples to accomplish marital success. The physical, mental, social, emotional, financial and spiritual difference has been blended into a harmonious relationship within the family bond. There is a high level of marital adjustment by the couples and to their children. Every member of the family: father, mother and children bring about this needed peace or stability.

In this study, family stability is seen as a situation where there is mutual understanding, love, care, fair treatment, fidelity and where the married couples enjoy family bliss. Families can be united where the couple develops a spirit of tolerance, love and consideration. In the absence of these, there is much tension which may lead to family instability that will need the intervention of the family counselor. When a family is stable, it means that male and female in the family are responsible.

\section{Statement of the problem}

Many teachers' marriages and families by extension in contemporary times in Nsukka are experiencing instability as revealed from literature. This has resulted in cases of infidelity, dishonest, distrust, spousal separation, and poor academic performance of the children, exposures of children to social vices due to parental conflicts or even total divorce in marriage. Communication builds up understanding and beats down differences that may lead to strange behavior. Hence, in the absence of effective marital communication, mutual understanding, acceptance, a free exchange of ideas and family cohesion will be lacking, unified action may not be possible between the husband and wife, and the offspring in such a family. Experiences have shown that ineffective marital communication generally may cause human 
mishaps and brings most family unhappiness and family instability among others.

\section{Purpose of the study}

The main purpose of this study is to investigate the influence of marital communication on the family stability of married teachers in the Nsukka Education Zone of Enugu State, Nigeria. Specifically, the study investigates:

(1) The pattern of marital communication flow employed by married teachers;

(2) Relationship between marital communication and family stability of married teachers.

\section{Research questions}

The following research questions were raised to guide the study:

(1) What are the patterns of marital communication flow employed by married teachers?

(2) What is the relationship between marital communication and family stability of married teachers?

\section{Hypotheses}

The following null hypotheses formulated were tested at a 0.05 level of significance:

Ho1: There is no significant difference between patterns of marital communication flow employed by a married teacher based on gender.

Ho2: There is no significant relationship between marital communication of married teachers and family stability.

\section{METHODOLOGY}

\section{Design of the study}

The thesis followed the analyzed style of a correlation survey. According to Nworgu (2015), the research design for correlation surveys is the type of study that seeks to determine the relationship between two and more variables.

\section{The population of the study}

The population of the study comprised 1,688 married teachers in the public secondary school in Nsukka Education Zone Enugu State, 342 for married males and 1,346 for married females (Nsukka - 1153, Igbo Etiti - 357 and Uzo-Uwani 178), according to Post Primary School Management Board Nsukka Area Workers Population (PPSMB 2017/2018).

\section{Sample and sampling techniques}

The survey for the Nsukka Education Zone research was 455 married teachers. The sample size consists of 162 married males from Nsukka Education Zone and 293 married females. The study adopted proportionate stratified random sampling techniques at $27 \%$ in order to arrive at 455 married teachers from all the public secondary schools in Nsukka Education Zone.

\section{The instrument for data collection}

The instrument for data collection was a structured questionnaire developed by the researcher to elicit a response that guided answers of the research questions and test the hypotheses. The questionnaire was structured from the literature reviewed. The instrument comprises two sections, A and B. Section "A" is concerned with demographic information of the respondents while section "B" elicit responses on general issues on Marital Communication and Family Stability (MCFSQ) concerning the research questions and hypotheses. MCFSQ has 16 items comprised cluster $\mathrm{A}$ and $\mathrm{B}$, seeking information on marital communication and family stability. The respondents responded to the questionnaire items on four-points rating scale with response option of Strongly Agree (SA) 4, Agree (A) 3, Disagree (D) 2, and Strongly Disagree (SD) 1 , respectively.

\section{Validation of the instrument}

The face validity of the instrument was done by three experts in the fields of Guidance and Counseling and Measurement and Evaluation. Two of the experts are from the Guidance and Counseling Unit, while one is from the Measurement and Evaluation unit all in the Faculty of Education, University of Nigeria, Nsukka.

\section{Reliability of the instrument}

The questionnaire on teacher's marital communication and family stability were subjected to trial testing using 30 respondents in Community Secondary School, Obollo Eke in Udenu Education Zone which is outside the study area, in other to determine the instrument's internal consistencies.

The response of the respondents from the trial test was subjected to reliability analysis using the Cronbach Alpha method. Cronbach Alpha System is chosen because the instrument was scored polychromous. Based on the analysis, reliability indices of 0.82 and 0.88 for marital communication and family stability questionnaire were reached respectively.

\section{Method of data collection}

The questionnaire on marital communication and family stability was administered to the married teachers by three (3) research assistants. The researchers had educated the research assistants about the purpose of the study and how to administer the questionnaire. The researchers and the research assistants administered the questionnaire to the respondents and these were collected on the spot to ensure a high return rate.

\section{Method of data analysis}

The data collected was analyzed using mean $(x)$ scores and standard deviation and Pearson Product Moment Correlation Coefficient with the use of a statistical package for social science version 21 (SPSS). T-test was used to test the null hypotheses one to two at 0.05 significant levels. The mean $(x)$ above 2.50 was considered acceptable, while any item below 2.50 was rejected. 
Table 1. Mean and standard deviation ratings of male and female married teachers on the patterns of marital communication flow they employ.

\begin{tabular}{|c|c|c|c|c|c|}
\hline Item statement & Gender & $\mathbf{N}$ & Mean & $\begin{array}{c}\text { Std. } \\
\text { Deviation }\end{array}$ & Decision \\
\hline \multirow{2}{*}{$\begin{array}{l}\text { 1. My partner and I communicate through telephone set } \\
\text { when we are away }\end{array}$} & Male & 160 & 3.24 & 0.72 & Agree \\
\hline & Female & 295 & 3.20 & 0.74 & Agree \\
\hline \multirow{2}{*}{ 2. My partner and I express our feeling without fear } & Male & 160 & 3.08 & 0.90 & Agree \\
\hline & Female & 295 & 3.06 & 0.91 & Agree \\
\hline \multirow{2}{*}{$\begin{array}{l}\text { 3. I and my partner do not allow third party in our family } \\
\text { discussion }\end{array}$} & Male & 160 & 3.08 & 0.71 & Agree \\
\hline & Female & 295 & 3.03 & 0.70 & Agree \\
\hline \multirow{2}{*}{ 4. We avoid poor parent-children communication } & Male & 160 & 3.01 & 0.74 & Agree \\
\hline & Female & 295 & 3.05 & 0.73 & Agree \\
\hline \multirow{2}{*}{ 5. I freely share ideas with my partner on daily basis } & Male & 160 & 3.00 & 0.73 & Agree \\
\hline & Female & 295 & 2.99 & 0.74 & Agree \\
\hline \multirow{2}{*}{ 5. My partner and I avoid veto power to take decision } & Male & 160 & 3.05 & 0.68 & Agree \\
\hline & Female & 295 & 2.99 & 0.71 & Agree \\
\hline \multirow{2}{*}{ 6. We use eye contact when we communicate } & Male & 160 & 3.24 & 0.77 & Agree \\
\hline & Female & 295 & 3.16 & 0.80 & Agree \\
\hline \multirow{2}{*}{$\begin{array}{l}\text { 1. The respect of each other's opinion helps in our } \\
\text { marital communication }\end{array}$} & Male & 160 & 3.18 & 0.75 & Agree \\
\hline & Female & 295 & 3.12 & 0.78 & Agree \\
\hline \multirow{2}{*}{ Overall Mean } & Male & 160 & 3.11 & 0.50 & Agree \\
\hline & Female & 295 & 3.07 & 0.52 & Agree \\
\hline
\end{tabular}

Table 2. Likelihood associated with the estimated value of $t(0.709)$ for the disparity in mean ratings between male and female married teachers on marital communication flow patterns.

\begin{tabular}{lcccccc}
\hline Gender & N & Mean & Std. Deviation & Df & t-cal & Sig. (2-tailed) \\
\hline Male & 160 & 3.11 & 0.50 & \multirow{2}{*}{453} & 0.709 & 0.479 \\
Female & 295 & 3.07 & 0.52 & & & \\
\hline
\end{tabular}

\section{RESULTS}

\section{Research question one: What are the patterns of marital communication flow employed by married teachers?}

Table 1 reveals that the mean ratings of both male and female married teachers to items $1,2,3,4,5,6,7$, and 8 are more than the criterion means of 2.50 . It indicates that both male and female married teachers are committed to the claims in items 1 through 8 as patterns of marital communication flow employed by married teachers.
Ho1: There is no significant difference between male and female married teachers' mean ratings on the patterns of marital communication flow employed by married teachers.

Table 2 shows that the likelihood associated with the estimated value of $t(0.709)$ for the disparity in mean ratings between male and female married teachers on marital communication flow patterns employed by married teachers is 0.479 . Since the probability value of 0.479 is greater than the 0.05 level of significance, the null hypothesis was not rejected. Thus, there is no significant difference between the mean ratings of male 
Table 3. Pearson's correlation analysis of the relationship between marital communication and family stability of married teachers.

\begin{tabular}{llcc}
\hline & & Family stability & Marital communication \\
\hline \multirow{2}{*}{ Pearson Correlation } & Family Stability & 1.000 & 0.613 \\
& Marital Communication & 0.613 & 1.000 \\
\multirow{3}{*}{ Sig. (1-tailed) } & Family Stability & - & 0.000 \\
& Marital Communication & 0.000 & - \\
$\mathrm{N}$ & Family Stability & 455 & 455 \\
& Marital Communication & 455 & 455 \\
\hline
\end{tabular}

and female married teachers on the patterns of marital communication flow employed by married teachers.

\section{Research question two: What is the relationship between marital communication and family stability of married teachers?}

Table 3 proves that the coefficient of association between marital communication and married teacher family stability is 0.613 . This suggests a moderate positive relationship between marital communication and married teacher family stability; thus implying that the more married teachers communicate, the more stable their family becomes.

Ho2: There is no significant relationship between marital communication and married teacher family stability.

Table 3 shows that the probability associated with the calculated $r(0.613)$ for the relationship between marital communication and family stability of married teachers, is 0.000 . Since the probability value of 0.000 is less than the 0.05 level of significance, the null hypothesis was rejected implying that there is a significant positive relationship $(p<0.05)$ between marital communication and family stability of married teachers.

\section{DISCUSSION}

\section{The pattern of marital communication flow employed by married teachers}

The findings of the study concerning research question one and hypotheses one showed that both male and female married teachers agreed to a pattern of marital communication flow which includes: communication through telephone when they are away, expressing feelings without fear, not allowing the third party in the family discussion, avoiding poor parent-children communication, freely sharing ideas with ones partner on daily basis, avoiding veto power to make a decision, using eye contact when communicating among others. It was further found that there is no significant difference between the mean ratings of male and female married teachers on the patterns of marital communication flow employed by married teachers. Most of the married teachers both male and female communicate through telephone set. It was noted also that the mean of married teachers who freely share ideas on daily basis is lower compare to other patterns of marital communication flow.

The result of the study revealed that communication is inevitable in marriage especially among married teachers. The study's results are in line with Nnadozie (2014) who found that communication is very vital for family stability. The findings of this study also support Esere et al. (2011) who found that most of the respondents agreed that lack of effective communication is the bane of marital stability.

\section{Relationship between marital communication and family stability of married teachers}

The findings of the study concerning research question two and hypotheses two showed there is a significant positive relationship between marital communication and family stability of married teachers. The positive relationship between marital communication and family stability of married teachers implies that effective use of marital communication makes the family stable. The findings of this study are against Usoroh et al. (2010) who reported that couples differed in modes of communication with a majority following a leveling approach. The analysis also showed that educational qualification was the specific variable that had a major effect on both communication styles and marital stability.

\section{Conclusions}

Based on the findings of the study, the following conclusions were drawn. This study showed that both 
male and female married teachers in Nsukka Education Zone agreed to the pattern of marital communication flow. The study also shows that there is a significant positive relationship between marital communication and family stability of married teachers in Nsukka Education Zone.

\section{EDUCATIONAL IMPLICATIONS}

The findings showed that marital communication through the telephone is a pattern of communication. This implies that teachers should always make use of their telephone for marital improvement. The study also revealed that married teachers have a major positive relationship between marital communication and family stability. This implies that the teacher's marital communication relates to family stability.

\section{RECOMMENDATIONS}

This study recommends that as a pattern of communication, a married teacher should not adhere strictly to one type of style, rather identifying the best pattern in the prevailing situation. Guidance counselors, psychologists, State and Federal Ministries of Education, should arrange marital communication conferences, workshops and symposia for married teachers. Guidance and counseling units should organize workshops on the relationship between marital communication and family stability.

\section{CONFLICT OF INTERESTS}

The authors have not declared any conflict of interests.

\section{REFERENCES}

Esere MO, Yusuf J, Omotosho JA (2011). Influence of Spousal Communication on Marital Stability" Implication for Conducive Home Environment. Educational Journal of Counselling 4(2):50-61.

Eze JU (2012). Family counselling in school setting in Anyawu. In: J. I. Anyanwu (Ed.), Marriage and family: Issues problem and counselling strategies. Snap Press.

Nnadozie ON (2014). Influence of Marital Communication on achieving Marital Stability among Married Teachers in Gusau Education Zone of Zamfara State. University of Nigeria, Nsukka.

Nworgu BG (2015). Educational research. Basic issues and methodology (2nd ed.). Nsukka: University trust publishers pp.45-99

Okonkwo H (2006). Effects of Communication on Family Stability: Implication for Counselors. University of Nigeria, Nsukka.

Okorodudu RI (2010). Fundamentals of marriage and family counselling. Abraka: Delta State University Press.
Onovo AM (2016). Needs For Joint Account For Family Stability and Marital Improvement of working class Husbands and wives in Enugu West Education Zone. University of Nigeria, Nsukka.

Patterson A, Yoevger B (2002). Intimate relationship in marriage. London: Avan.

Salami OB (2007). Marital Instability in Nigeria: Implication on Growing up Children. University of Nigeria, Nsukka.

Tambuwal H (2007). Family stability: Implication for national development. Journal of Marriage and the Family 20(1): 796-806.

Usoroh C, Ekot MO, Inyang ES (2010). Spousal Communication Styles and Marital Stability Among Civil Servants in Akwa-lbom State. Journal of Hydro-environment Research 13:74-84.

Uwakwe BC (2008). Effect of communication skills on family stability. Talata: Umaro Printing press. 